\title{
Balancing freedom of expression and the right to reputation: reflections on Reynolds and reportage
}

\author{
ERIC BARENDT
}

Emeritus Professor of Law, University College London*

\section{Introduction}

$\mathrm{T}$ The Law Lords in Reynolds $\mathrm{v}$ Times Newspapers ${ }^{1}$ were fully aware of the importance of the two rights at stake in the case - the right to freedom of expression and the right to reputation - and the need to strike an appropriate balance between them. For Lord Nicholls in the Lords" leading speech, the "starting point is freedom of expression" and " $t$ the high importance of freedom to impart and receive information and ideas", but he also brought out the significance of the right to reputation which is to be regarded as "an integral and important part of the dignity of the individual". ${ }^{2}$ Its protection was not only in the public interest, but it further served the interests of the individual whose standing might be ruined for ever by the publication of defamatory allegations, whether they were true or false. Without an enforceable right to reputation a politician or other prominent figure might be unjustly hounded out of public life, while ordinary individuals might find it impossible to secure employment or do business unless they can clear their name.

In that landmark case, the House of Lords formulated an extended qualified privilege defence to a libel action, so that the defendant is not liable if he or she has published false defamatory allegations on a matter of public interest, provided that in publishing them the requirements of "responsible journalism" have been satisfied. It became clear in later decisions that this amounted to a new form of qualified privilege, ${ }^{3}$ quite different from the traditional heads of this privilege where the question is whether the defamatory allegations have been published on a privileged occasion, for example, in the course of communications between civil servants or in a reference sent to a prospective employer. For the first time in English law the media may have a defence if it publishes untrue factual defamatory allegations on a matter of public interest, as long as it has behaved responsibly by, for example, relying on trustworthy sources and by checking the story with the claimant and others before deciding to publish it. Reynolds took greater account of freedom of

\footnotetext{
I am indebted to Richard Rampton QC, Paul Mitchell, Jason Boland and an anonymous reviewer for their comments on a draft of this article.

1 [1999] 4 All ER 609.

2 Ibid. at 621-22.

3 See Loutchanksky v Times Newspapers [2002] 1 All ER 652, where Lord Phillips MR said, at para. 35, that "Reynolds privilege is ... a different jurisprudential creature from the traditional form of privilege from which it sprang”.
} 
expression than the common law had previously done. Before the decision, English common law had generally been thought to be too solicitous of reputation rights and too little concerned with freedom of speech and press freedom. ${ }^{4}$

But it would be wrong to think that English libel law had altogether ignored freedom of expression before the decision in Reynolds. It is perhaps worth recalling how the freedom has been recognised in other aspects of this area of law:

(i) A public body cannot bring defamation proceedings at all, because its entitlement to sue for libel would be incompatible with freedom of expression. ${ }^{5}$ The principle has been extended to bar defamation actions by political parties. 6

(ii) Truth is a complete defence to a libel action. In English law it is assumed that the disclosure of true allegations is in the public interest, because otherwise the public would assess the standing of the claimant on the basis of a misconception. This is a freedom of speech argument, which can be linked to Mill's well known argument for liberty of discussion as a means for the discovery of truth. ${ }^{7}$

(iii) Similar arguments underlie the defence of fair comment (to be renamed under the government's recent Draft Defamation Bill as "Honest Opinion"). ${ }^{8}$ In this instance, the defence is based as much on the free speech rights of the speaker to express his/her honest views on the reputation of an individual or the quality of a play, film or other work, as it is on the interests of the public in assessing these views. ${ }^{\text {? }}$

(iv) Freedom of speech is the reason for the defences of both absolute and qualified privilege. This is perhaps most obviously the case for the absolute privilege of Members of Parliament to speak freely in the course of parliamentary proceedings, conferred by Article 9 of the Bill of Rights 1689 . But it is also true of the absolute privilege, say, of parties and witnesses to legal proceedings to give evidence without the fear of libel proceedings ${ }^{10}$ and of the numerous heads of qualified privilege. Notably, the recognition of the qualified privilege for fair reporting of parliamentary debates was explicitly justified by reference to the importance of free discussion of what was said in Parliament. ${ }^{11}$ In all these cases, the common law recognises that defamation law may exercise a "chilling effect" on freedom of speech: it may deter the communication of information, which is valuable either to the general public or to a class of potential recipients (e.g. prospective employers) on future occasions, if the particular defendant can be sued for libel.

(v) Finally, freedom of speech is the principal reason why the courts are unwilling to grant an interim injunction to restrain the further publication of

\footnotetext{
4 See the remarks of Lord Hoffmann in Jameel v Wall Street Journal Europe SPRL [2007] 1 AC 359, para. 38.

5 Derbyshire County Council v Times Newspapers [1993] AC 534 HL.

Goldsmith v Bhoyrul [1998] QB 459 (Buckley J).

J S Mill, "Of the liberty of thought and discussion", On Liberty and Other Essays (Oxford: OUP 1961).

8 Draft Defamation Bill, cl. 4.

9 See the judgments of Diplock J in Silkin v Beaverbrook Newspapers Ltd [1958] 1 WLR 743, at 745, and of Lord Denning MR in Slim v Daily Telegraph Ltd [1968] 2 QB 157, 170 (CA).

10 Munster v Lamb (1883) 11 QBD 588, 697 per Fry LJ.

11 See the judgment of Lord Cockburn CJ in Wason v Walter (1868) 4 QB 73, 89. Also see Lord Diplock in Horrocks v Lowe [1975] AC 135, 149-50.
} 
defamatory material before full trial. The grant of such an injunction would stop the publication of the truth or of allegations which could be successfully defended as fair comment or as covered by a defence of privilege, and that would infringe freedom of speech. ${ }^{12}$

Nevertheless it is through the defence of Reynolds privilege and the associated reportage defence that English law most clearly balances the rights to freedom of speech or expression on the one hand against the right to reputation on the other. It does this through a careful consideration of a number of factors, relevant to determining whether the defendant has satisfied the requirements of "responsible journalism"; they are set out in the famous "check-list" drawn up by Lord Nicholls in Reynolds and are now listed, albeit in slightly different terms, in cl. 2(2) of the Draft Defamation Bill which was issued by the Ministry of Justice in March 2011.

This article is concerned entirely with Reynolds privilege and the related reportage defence. The next section reviews the present common law, concentrating on the recent decision of the Court of Appeal in Flood v Times Newspapers Ltd; ${ }^{13}$ and it then briefly examines the relevant provisions of the Draft Defamation Bill. Section 3 makes a number of general points about the approach in Reynolds (and under the new Bill) to balancing freedom of speech and reputation rights, while Section 4 explores three issues which have not yet been fully resolved, or even properly canvassed, in applying the defence. Section 5 discusses the reportage defence, usually treated as a variety of Reynolds qualified privilege, but which is sometimes regarded, notably in a stimulating recent article by Jason Boland, ${ }^{14}$ as doctrinally distinct and as resting on quite different principles. One point to emerge from these reflections is that Reynolds privilege may not provide a coherent approach to the balancing of freedom of expression and reputation rights. Secondly, the reportage defence, whether or not it is regarded as a variety of Reynolds, should not be treated expansively, since that might allow the media too wide a freedom to report inaccurate stories and rumours.

\section{The Reynolds defence in English common law}

Any hopes that the decision in Reynolds would greatly expand the freedom of the media to publish untrue defamatory allegations of real interest to the public were soon dashed by the approach of the courts in the following five or six years. The defence failed in the vast majority of the cases in which it was argued. The courts treated the factors itemised by Lord Nicholls in Reynolds, to be considered when determining whether the media defendant had satisfied the requirements of "responsible journalism", as hurdles for it to clear. If the court found, for example, that a newspaper had relied on an untrustworthy source with an "axe to grind", 15 or alternatively that it had made no serious attempt to contact the claimant to get the other side of the story, ${ }^{16}$ then the defence would fail, irrespective of the strength of other factors which might point to the conclusion that overall the story had been published responsibly.

However, the decision of the House of Lords in Jameel v Wall Street Journal Europe SPRL was generally thought to have corrected this approach and indeed to have tilted the scales a little in favour of freedom of expression. ${ }^{17}$ In that case the claimants, a Saudi Arabian

12 Bonnard v Perryman [1891] 2 Ch 269, 283 per Lord Coleridge CJ.

13 [2010] EWCA Civ 804, [2010] EMLR 26, [2011] 1 WLR 153.

$14 \mathrm{~J}$ Boland, "Republication of defamation under the doctrine of reportage - the evolution of common law qualified privilege in England and Wales" (2011) Oxford Journal of Legal Studies 89.

15 As in James Gilbert v MGN [2000] EMLR 680 (Eady J).

16 As in Galloway v Daily Telegraph Group Ltd [2006] EMLR 11 (CA).

17 [2007] 1 AC 359. 
trading company and its general manager and president, brought proceedings in respect of an article in which they were named as among the persons whose bank accounts were being monitored by the Saudi Monetary Authority at the request of the US law enforcement agencies, to see whether they were being used, knowingly or not, to support terrorist organisations. The lower courts had rejected Reynolds privilege on the grounds that first, it was not in the public interest to name the claimants as persons whose accounts were being monitored, and, second, because Jameel had not been given a chance to comment on the story before its publication. ${ }^{18}$ The House of Lords allowed the defendant's appeal, dismissing both these reasons for rejecting the defence. On the first point, whether the subject matter of the article was a matter of public interest, and therefore covered by the privilege (subject to satisfaction of the responsible journalism test) should be determined by considering the article as a whole and not by reference to the defamatory statement in isolation. ${ }^{19}$ The overall story that the Saudi authorities were monitoring company accounts in cooperation with the US government was plainly a subject of public interest. It was then a matter for editorial judgment whether it was appropriate to name the claimants in order to give the story greater credibility. On the second point, the Lords ruled that the lower courts had applied the "opportunity to comment" requirement inflexibly; in this case it was pointless to delay publication of a responsibly researched, serious story until Jameel had been given an opportunity to comment on the allegation, for he would not have been able to say anything other than that he could see no reason why the Saudi authorities should be monitoring his accounts ${ }^{20}$ More generally, the Law Lords emphasised that the factors listed by Lord Nicholls should be treated as flexible considerations, the precise weight and importance of which would vary according to the circumstances of each case. ${ }^{21}$

The courts have now adopted this more flexible approach to the Reynolds defence required by Jameel. But the significance of the later Lords ruling may have been limited by the decision of the Court of Appeal in Flood v Times Newspapers. 22 The newspaper in that case had published an allegation that the claimant, a Detective Sergeant (DS) in the Metropolitan Police Service (MPS), had taken bribes from a security company to supply it with information concerning attempts by the Kremlin to extradite opponents of the government in Russia. The MPS had issued a press release to the effect that an unnamed serving officer was under investigation for making unauthorised disclosures of information in return for money; the investigation subsequently cleared DS Flood, so that the allegations could not be justified. Tugendhat J held, following Jameel, that the story overall that a police officer is under investigation for bribery was one of public interest, and that it was within editorial discretion to name that officer to give it additional credibility. ${ }^{23}$ The Court of Appeal reversed his decision. It held that publication of the allegations against DS Flood was not protected by Reynolds privilege; the newspaper had not made any real attempt to check or verify these serious allegations, which the newspaper had no urgent need to publish. So the requirements of responsible journalism were not met. The claimant conceded that reporting the police press office statement that a police officer was under investigation was covered by qualified privilege. ${ }^{24}$ Further, it was legitimate to name the police officer, for that

18 [2004] EMLR 106, Eady J and [2005] QB 904 (CA).

19 See n. 17 above, para. 48 (Lord Hoffmann).

20 Ibid. para. 84 (Lord Hoffmann).

21 Ibid. paras 33 (Lord Bingham), 56 (Lord Hoffmann).

22 See n. 13 above.

23 [2010] EMLR 8.

24 Defamation Act 1996, s. 15(1) and para. 9 of the Schedule confers statutory privilege on reports of notices issued to the public by bodies exercising governmental functions. 
did add credibility to the report. However, the Court of Appeal accepted the claimant's argument that this case was distinguishable from Jameel, where the article had merely reported that the bank accounts were being monitored; that article had not made any precise allegations, nor had it disclosed evidence to show that the accounts were being used to finance terrorism. In contrast in Flood, "the allegations were the whole story". 25 The Court of Appeal accepted the claimant's argument that it was not in the public interest to report the precise allegations against him, for otherwise the press would be free to publish unfounded, perhaps even malicious, allegations against police officers with the risks of trial by media. ${ }^{26}$ (In October 2011 the appeal of Times Newspapers against the Court of Appeal's decision was heard in the Supreme Court. Unfortunately, the Supreme Court decision was not available at the time of going to press.)

A few significant points in the decision of the Court of Appeal in Flood are hard to interpret. As will be discussed in Section 5 of this article, some of its reasoning may be attributable to an anxiety not to extend the reportage defence. The major uncertainty concerns whether the Court of Appeal ruled that the publication of details of allegations of this kind against a named individual can rarely, if ever, be regarded as warranted, even when an editor understandably considered their publication necessary to give colour to the publication of a news report which itself would be covered either by statutory or by Reynolds privilege. Some passages in the judgments might be read to support that broad interpretation. In Lord Neuberger MR's view: ${ }^{27}$

[it] would be tipping the scales too far in favour of the media to hold that not only the name of the claimant, but the details of the allegations against him, can normally be published as part of the story free of any right in the claimant to sue for defamation just because the general subject matter of the story is in the public interest.

But the fact that the court went on to consider how far the newspaper had made serious attempts to verify the details suggests it was not going as far as that. The implication is that if The Times had made such attempts, the Reynolds defence might have succeeded; in contrast, that defence would not have covered the case at all if the publication of detailed allegations of this kind against a claimant is never to be regarded as a matter of public interest. But even if strenuous efforts had been made to check the story, it is unclear that the defence would have succeeded. For it was also suggested that responsible journalism required the newspaper to refrain from putting allegations to DC Flood, when he could not properly comment on them at a time when the MPS investigation was being conducted. ${ }^{28}$ That itself is a novel application of the responsible journalism test, ${ }^{29}$ which normally requires defamatory allegations to be put to the potential claimant for comment and to provide his/her version of events. ${ }^{30}$

At this point it is worth emphasising an important feature of the Reynolds defence. There are two stages in its application. The first is the question whether it is in the public interest to publish the defamatory allegations, or after Jameel whether it is in the public interest to publish the story, of which the allegations form a part. That may be described as the

25 See n. 13 above at para. 100 per Moore-Bick LJ (emphasis in the original).

26 Ibid. para. 104.

27 Ibid. para. 63.

28 Ibid. para. 104 per Moore-Bick LJ and para. 116 per Moses LJ.

29 P Mitchell, "The nature of responsible journalism" (2011) 3 Journal of Media Law 19, pp. 26-7.

30 For a recent decision in Northern Ireland holding that Reynolds privilege could not be claimed, because the newspaper failed to invite comment from the claimant or at least obtain the gist of her side of the story, see O’Rawe v Trimble [2010] NIQB 135, paras 88-94 per Gillen J. 
threshold inquiry. ${ }^{31}$ It is relatively rare for the defence to fail at this stage; it is unclear that it did in Flood itself. The courts have taken a broad view of the scope of matters of public interest and concern, just as they have done when determining the scope of the fair comment defence. It would surely be difficult to justify an unqualified ruling that the publication of detailed allegations against police officers or other public officials can never, or virtually never, be a matter of public concern; there is a great deal of legitimate public interest in their probity. The second stage is the responsible journalism test. "[T] he extent to which the subject matter is a matter for public concern" is one of the factors listed by Lord Nicholls, which in conjunction with others determines whether freedom of expression or reputation should be given the greater weight on the facts of the case. The Court of Appeal in Flood was on firm ground insofar as it decided that the freedom of expression interest in disclosure of the detailed allegations against the claimant was of little weight when balanced against the impact of the disclosure on his reputation ("the seriousness of the allegation" - another consideration in the Nicholls check-list), particularly as it was clear that the defendant had not made any rigorous attempt to verify them. If that is all the court decided, the decision can be supported.

There is one point on which Flood is clearly right. In Reynolds, Lord Nicholls had said that "[a]ny lingering doubts should be resolved in favour of publication", because the courts should pay particular regard to the importance of freedom of expression. ${ }^{32}$ Both Tugendhat $J$ and the Court of Appeal in Flood considered this principle incompatible with the equal weight which must be attached to the Convention rights under Articles 8 and 10.33 Neither the right to respect for private life (including the right to reputation) nor the right to freedom of expression is entitled to priority over the other - a proposition accepted by the House of Lords in $\operatorname{Re} S$ (A Child). ${ }^{34}$ So the balancing exercise required by Reynolds does not begin or end with any presumption in favour of freedom of expression, a strong contrast with the United States rule discussed in the next section of this article, under which the constitutional free speech and press rights trump the common law right to reputation. ${ }^{35}$

The provisions in the government Draft Defamation Bill on the defence of responsible publication on a matter of public interest reflect the common law position. Under cl. 2(1) "[ i]t is a defence for the defendant to show that (a) the statement complained of is, or forms part of, a statement on a matter of public interest", and (b) he or she acted responsibly in publishing the defamatory allegations. Clause $2(2)$ then sets out the matters to which the court may have regard when determining whether the defendant had acted responsibly in publishing them. They reproduce the check-list drawn up by Lord Nicholls, albeit expressed in slightly different terms. Unlike Lord Lester's Private Members' Bill, drafted in 2010 and given a second reading in the House of Lords in July that year, the clause explicitly mentions the "tone of the statement (including whether it draws appropriate distinctions between suspicions, opinions, allegations, and proven facts)". 36 So tabloid newspapers and bloggers must be careful not to present a suspicion of wrong-doing as if it were a proven fact, nor should they give it excessive prominence or present it in a

31 See the analysis in D Milo, Defamation and Freedom of Speech (Oxford: OUP 2008), pp.109-13

32 See n. 1 above, at 626.

33 See n. 13 above, para. 21, per Lord Neuberger MR, approving the remarks of Tugendhat J, n. 23 above, para. 146.

34 [2005] 1 AC 593.

35 See s. 3(i) below.

36 The Joint Committee of the House of Lords and House of Commons on the Draft Defamation Bill (12 October 2011, HL Paper 203, HC 930-1) has recommended that the words in parentheses should be removed, as they would lead to excessive analysis of any text containing defamatory allegations (see para. 65d). 
sensational manner, if they want to claim the statutory defence. ${ }^{37}$ The clause in the government Bill wisely does not include the provision in the Lester Bill, which seems to have required courts to have regard to the extent of the defendant's compliance with any relevant code of conduct, such as that of the Press Complaints Commission (PCC); the provision might have complicated court cases by encouraging arguments over the interpretation of the PCC or other code, so spawning what is termed "satellite litigation". Interestingly, cl. 2 of the Bill, unlike its provisions reformulating the defences of truth and fair comment, does not abolish the common law; presumably, therefore, the leading decisions in Reynolds and Jameel remain authoritative. Indeed, it is conceivable that, if the Bill is enacted, the media might argue in appropriate cases that it has a defence either under the provisions of the new Defamation Act or under the common law Reynolds privilege; 38 it is more likely that the courts will interpret the provisions against the background of the leading common law rulings.

\section{An assessment of Reynolds from a comparative perspective}

\section{(I) Detailed ad hOC BALANCING}

One important aspect of the decision in Reynolds was its rejection of a wide generic privilege for the publication of political information. That privilege would not do justice to the right to reputation, and moreover it would inappropriately distinguish the treatment of untrue allegations about politics from similar statements of equivalent public concern about other topics. ${ }^{39}$ Instead, it was better, in the view of the House of Lords in Reynolds, for the courts to weigh the importance of freedom of expression against the reputation right in the light of all the factors of the case, which showed whether the defendant had satisfied the requirements of responsible journalism. As Lord Nicholls put it in Bonnick v Morris, "[r] esponsible journalism is the point at which a fair balance is held between freedom of expression on matters of public concern and the reputations of individuals". 40 This is detailed, ad hoc balancing, with full consideration given to a range of factors, the weight of which will vary from case to case. The same approach seems to have been taken recently by the Court of Appeal in a traditional qualified privilege case, when it ruled that all the facts should be considered in determining whether the defendant local authority had a duty to communicate defamatory allegations about the claimant to a wide range of its employees; the fair balancing of reputation and freedom of expression meant that the defendant could not claim that any communication to all its staff is necessarily made on a privileged occasion. ${ }^{41}$

This approach contrasts with that of some other courts, most notably that of the United States Supreme Court which has adopted what is termed rule or "definitional" balancing. ${ }^{42}$ Under the rule in New York Times $\mathrm{v}$ Sullivan, ${ }^{43}$ as extended in later decisions, if a defamatory allegation is made of a public official or figure, that person must prove actual malice for a libel action to succeed, that is, he or she must show that the defendant knew

37 Grobbelaarv News Group Newspapers [2001] 2 All ER 437, where the Court of Appeal held that Reynolds privilege could not be claimed for sensational articles in The Sun alleging that a goalkeeper was guilty of match-fixing would surely be decided the same way under these provisions.

38 The Joint Committee recommended that the common law defence should be repealed: n. 36 above, para. 63.

39 See Lord Nicholls in Reynolds, n. 1 above, at 625.

40 [2003] 1 AC 300, para. 23.

41 Clift v Slough Borough Council [2010] EWCA Civ 1171, [2011] EMLR 13.

42 The distinction between definitional and ad hoc balancing is drawn and defended in a classic article by M B Nimmer, "The right to speak from Times to Time: First Amendment theory applied to libel and misapplied to privacy” (1968) 56 California Law Review 935.

43376 US 254 (1964). 
that the allegation was false and defamatory of the claimant, or that the defendant was reckless about its truth. It is immaterial how damaging the allegation was, how careful the defendant had been in investigating and publishing the story, or whether the story was really of great concern to the public. The only material factor is the status of the claimant: public official or figure on the one hand, or private person on the other. The publication of a story about a candidate for a local office - hardly a person whose conduct is of great interest to the public - was therefore caught by the New York Times rule, even though the newspaper had made a shocking mistake and its coverage may have ruined the life of the claimant. ${ }^{44}$ Of course English law takes a rule-based approach with regard to the justification (or truth) defence; the publication of an accurate defamatory allegation can always be defended successfully, whether or not it concerns a matter of public interest and however much it damages the standing and feelings of the claimant. ${ }^{45}$

The English approach in Reynolds is much less crude than that adopted by the United States Supreme Court, which can only be explained in terms of the priority given in the United States to freedom of speech. That freedom is as a matter of constitutional law entitled to much greater weight than the rights to reputation (or for that matter to personal privacy in media cases) which are not protected at all as constitutional rights. Two points may be made, however, against the approach in Reynolds, which is now consistently followed by the courts in England and Northern Ireland. 46 The second is considered later in this section of the article. ${ }^{47}$ The first is that ad hoc balancing does not remove the "chilling effect" of English libel laws, or at least remove it as much as the media had hoped. This point was made by the New Zealand Court of Appeal, when it declined to adopt a responsible journalism test as a condition for upholding a broad qualified privilege defence in respect of the publication of defamatory allegations about politicians and candidates for elected office. ${ }^{48} \mathrm{~A}$ broad rule like that adopted in New Zealand or the New York Times actual malice rule provides much more certainty for the media and therefore better protects freedom of expression.

Though Reynolds is regarded as a valuable addition to the range of defences which the media may invoke when faced with defamation proceedings, they have have found the courts generally unsympathetic to it and its application to be unpredictable. ${ }^{49}$ Journalists, editors and others have to determine what steps they must take to satisfy the requirements of responsible journalism, generally at times when they are under intense pressure to meet deadlines and when it may be hard to contact potential claimants to ask for their comments and to find out their side of the story. Moreover, journalists must determine not only whether they have taken what they, or their profession, regard as reasonable steps, but they must predict whether the libel judge will find that they have complied with the requirements of responsible journalism. So Reynolds clearly does not remove the chilling effect of libel law, but, of course, claimants, and others anxious to defend reputation rights, will argue that this is no bad thing. In their view, newspapers and other defendants ought to be very cautious

44 See Ocala Star Banner Co. v Damron 401 US 295 (1971), where the newspaper mistakenly reported that a candidate for local office faced perjury charges, when in fact the charges related to his brother. This irresponsible journalism was covered by the New York Times rule, so the claimant could only bring a successful defamation action if he proved actual malice.

45 The same is true to some extent of the fair comment defence, though the public interest requirement enables the court in principle to consider a range of factors.

46 See O'Rawe v Trimble, n. 30 above, for a Northern Ireland decision closely following Reynolds.

47 Section 3(iii) below.

48 Lange v Atkinson (No 2) [2000] 3 NZLR 385. The New Zealand courts had been invited by the Privy Council ([2000] 1 NZLR 258) to consider the principles in Reynolds, but rejected them.

49 See the study by A T Kenyon, Defamation: Comparative law and practice (London: UCL Press 2006), pp. $223-31$. 
before publishing defamatory allegations; it is right for libel law to chill, or deter, the publication of sloppy or over-hasty journalism. ${ }^{50}$

\section{(II) REYNOLDS AND THE APPROACH OF OTHER COURTS}

The ad hoc, detailed factual balancing approach of Reynolds is taken by many other top courts, although, as we have seen, the United States Supreme Court and the New Zealand Court of Appeal have formulated rules which give significantly greater protection to the publication of defamatory allegations about public officials and figures (United States) or about politicians and election candidates (New Zealand). But the High Court of Australia 51 and now the Supreme Court of Canada take a similar approach to that taken by the English courts. In Grant v Torstar Corporation, the Supreme Court of Canada formulated a new constitutional defence of responsible communication on a matter of public interest to defamation actions. ${ }^{52}$ The defence is to apply when the publisher was diligent in attempting to verify the allegations, having regard to eight factors, some of them formulated in terms strikingly similar to those listed by Lord Nicholls and now set out in the UK government's Draft Defamation Bill.

Of greater relevance for defamation law in the United Kingdom is that the Reynolds approach reflects that taken by the European Court of Human Rights in its extensive defamation jurisprudence. In determining the balance between the Convention right to freedom of expression under Article 10 of the European Convention on Human Rights (ECHR) and the right to respect for private life, now embracing the right to reputation, under Article $8 \mathrm{ECHR}$, the court considers how the national courts have weighed a number of factors: the character of the allegations (fact or value-judgment), their wording and seriousness, the steps taken by the defendant to verify the allegations, and the sources or other evidence for the story. ${ }^{53}$ The status or position of the libel claimant is a factor, ${ }^{54}$ though not, as in the United States or New Zealand, decisive. The seriousness of the penalty or level of damages is also relevant in determining whether there has been a disproportionate interference with the right to freedom of expression.

The European jurisprudence is important, of course, because courts in the United Kingdom must adopt a similar approach, if recourse to Strasbourg is to be avoided. They would infringe the Convention if they adopted the US approach, under which priority is given to freedom of speech at the expense of reputation and privacy rights. A rule such as that in New York. Times would not strike a fair balance between freedom of expression and the right to respect for private life (including now the right to reputation), or put another way, it would amount to a disproportionate infringement of the latter right. An approach like that taken in Reynolds is therefore mandatory, as a matter of UK human rights law, irrespective of whether it is the best approach to balancing these two fundamental rights.

\section{(III) THE COHERENCE OF THE REYNOLDS APPROACH TO BALANCING}

The principal argument against the approach in Reynolds raises some complex issues. A fundamental question is whether responsible journalism is the most appropriate point at which to strike a fair balance between the right to reputation and freedom of expression, as

50 This was also the view of Lord Hoffmann in The Gleaner v Abrahams [2004] 1 AC 628, para. 72, PC.

51 Lange v Australian BroadcastingCorporation (1997) 189 CLR 520.

52 [2009] 3 SCR 640.

53 See the cases discussed in E Barendt, "Balancing freedom of expression and privacy: the jurisprudence of the Strasbourg court" (2009) 1 Journal of Media Law 49, pp. 60-6, 70-2.

54 Lingens v Austria (1986) 8 EHRR 407, paras 41-3. 
was maintained by Lord Nicholls in Bonnick. 55 There can be little doubt that the threshold question in Reynolds - whether the statement was on a matter of public concern or interest - is highly relevant to striking this balance. If the defamatory allegation concerns private behaviour of no real public concern, there is very little to put in the scales to weigh against the reputation right. Equally, it can be argued that an irresponsible newspaper, or other defendant, has only a weak claim to freedom of expression, so it is legitimate to take the requirements of responsible journalism into account when balancing its rights against those of a libel claimant.

But the argument is quite different if we conceive freedom of expression as guaranteeing the right of the public to be informed on matters concerning politics and other matters of legitimate public concern. The effect of the responsible journalism test is that the balance between the public's right to receive information and the right to reputation is determined by focusing to a large extent on the conduct of the media - which may be the public's watchdog, but is hardly its agent. Sometimes that might be thought right. As Lord Hobhouse pointed out in Reynolds, there is no public interest in publishing or communicating misinformation - "there is no interest in being misinformed". 56 The responsible journalism test is intended to avoid that danger by ensuring, so far as possible, that the public receives information believed on good grounds by the media to be true, though it later turns out to be false. The problem, however, with this justification for the responsible journalism test is that some of the criteria for its application do not appear to be clearly relevant to the importance, or even the reliability, of a public interest story, the dissemination of which Reynolds is intended to protect. A failure by the journalist to verify the allegations or to wait for the claimant's comments certainly has nothing to do with the significance of the story which the public has a free speech right to read or hear. ${ }^{57}$ It is not even clear that these failures necessarily shake its reliability. These criteria bear on the conduct of the press or other media, but not on the public's right to freedom of expression.

Moreover, the responsible journalism test hardly does justice to the chilling-effect argument. There is surely sometimes a public interest in receiving information which the press considers, albeit wrongly, to be accurate, but which it may decide not to publish, as it lacks confidence that a court would hold it had satisfied the requirements of responsible journalism. It may fear that the court will decide that the journalist investigating the story has carried out too few checks or that he or she should have waited longer to make contact with an elusive claimant before publishing the story. In summary, the responsible journalism test in these circumstances does not operate satisfactorily to balance the interests of the public and those of the libel claimant. Moreover, defamation law may still exercise an undesirable chilling effect on freedom of expression.

The solution to this conundrum, if it is one, surely lies in reformulating, or perhaps simply a more sensitive application of, the Reynolds balancing formula. If the information is of clear public interest and publication is really urgent - an important vote in the House of Commons or at a shareholders' meeting may go one way if it is released and the other way if it is not - it would seem wrong to require satisfaction of the other requirements of responsible journalism. Other solutions are also available which would provide some remedy, or compensation, for libel claimants, without inhibiting the freedom of the media to publish stories of real public interest. It might, for instance, be made a condition for

55 See n. 40 above.

56 See n. 1 above, at 657.

57 On the other hand, the first two factors in the Nicholls check-list - the seriousness of the allegation, and its nature and the extent to which the subject-matter is one of public concern - are clearly relevant to freedom of expression. 
Reynolds privilege that the media subsequently publishes a correction of its false story, perhaps agreed with the claimant who would otherwise be entirely without redress for the publication of an inaccurate and defamatory story. A right of reply or correction for defamation victims would arguably exercise less of a chilling effect than large damages awards and the attendant legal costs of fighting a libel action, though it would be resisted very strongly by the media owners and editors on free press grounds. There is, of course, a precedent for this sort of provision in the Defamation Act 1996; in some instances the qualified privilege defence is available for a fair report only if the defendant has complied with the claimant's request to publish a reasonable "statement by way of explanation or contradiction". 58 Alternatively, in those cases where Reynolds privilege is upheld and the press (or other defendant) declines to publish a reply or correction, some modest compensation might be awarded to the claimant for the injury to his/her reputation rights. Availability of these remedies would not interfere disproportionately with freedom of expression, while it would show some respect for the claimant's reputation rights. ${ }^{59}$ The weakness of the present law is that it provides an all-or-nothing solution: if the Reynolds defence is upheld, the claimant's reputation is entirely sacrificed to freedom of expression and the press, while if the defence is rejected - perhaps because the journalist has not carried out enough checks - the media must pay damages in respect of a story, even if it has real public interest, and freedom of expression loses.

\section{Unresolved questions}

I have identified three sets of circumstances in which it may be difficult to determine how the Reynolds responsible journalism test should be applied. In two of them there is some authority, but the caselaw does not resolve all the difficulties, while on the third there is virtually no authority at all. There are probably other issues to resolve. On them, as on those discussed below, further enlightenment is to be expected as the caselaw develops.

\section{(I) OPPORTUNITY TO COMMENT}

When is it unnecessary to ask the claimant for his comments on the story which the media would like to publish and for his side of the story? Normally this is required under the Reynolds check-list; indeed the failure to put the story to Albert Reynolds was one of the factors which persuaded the majority of the House of Lords to dismiss the appeal of the Sunday Times in that case. On the other hand, in Jameel the Law Lords held it was unnecessary to wait for Jameel's comment on the story, as it was most unlikely he would have been able to say anything of value about it. It is clear from one later case that the failure to put allegations to the claimant is not necessarily decisive for rejection of the defence. ${ }^{60}$ But it is for the defendant to show that it was responsible for the media not to ask for comment from the claimant, not for the latter to show that he or she would have been able to add something of value. ${ }^{61}$

The question may often be how long the defendant ought to try to track the claimant down before publishing its story, particularly when it believes on perhaps reasonable grounds that the claimant could only issue an anodyne denial of its truth. There are of course good free speech grounds for the conclusion that, generally, the media should delay publication until it has managed to contact the claimant; after all the claimant's comments provide his/her version of events, amounting in effect to the exercise of a right of reply

58 S. $15(2)$.

59 See the arguments of F Schauer, "Uncoupling free speech" (1992) 74 Columbia Law Review 691.

60 Armstrong v Times Newspapers [2005] EMLR 33, para. 82 (CA).

61 Prince Radu of Hohenzollern v Houston [2009] EMLR 13 (CA). 
issued contemporaneously with, rather than after, the media publication. On the other hand, the media may be under considerable pressure to get its story out; there may be much less public interest in a delayed publication.

In some circumstances, a claimant may prefer not to comment on the allegations at all, fearing that this would give them greater publicity or perhaps because any comments might prejudice an inquiry into the claimant's conduct. Further, as already mentioned, ${ }^{62}$ the Court of Appeal in Flood said it was against responsible journalism to expect DS Flood to comment on the unsubstantiated allegations which had been made against him, pending an MPS investigation of their truth. His "right to silence" at that stage was used to reinforce the court's conclusion that it was against the public interest to publish the detailed allegations which had been made against him. It is unclear whether the Court of Appeal would have taken the same view if The Times had obtained clearly reliable sources for its story and had made rigorous attempts to check the accuracy of that story - so that most of the requirements of responsible journalism would have been amply satisfied. In those circumstances it would surely be wrong for the newspaper not to give the claimant an opportunity to comment on the story - even though he might not be able to say much until the police investigation had been completed.

\section{(II) THE SERIOUSNESS OF THE ALLEGATIONS}

This was the first of the 10 factors in Lord Nicholls' check-list. He added that the more serious the allegation, the more the public is misinformed and the greater the harm to the individual if the charge is untrue. Equally it can be said that the public has a greater interest in hearing of serious allegations against, say, a politician or other prominent figure, at least if the media believes them on good grounds to be true. So the factor arguably cuts both ways. In privacy cases, the courts take into account the type of expression: does it concern politics or other matter of public concern or does it amount to no more than celebrity gossip? In defamation cases too, the character of the overall story may be crucial, as in Jameel, to striking the balance between freedom of expression and reputation rights. Arguably the courts should take account not only of the seriousness of the allegations in themselves - whether for example they concern the claimant's public life, or only a minor aspect of the claimant's social or personal relationships - but also of the likely extent or level of damage to the claimant's self-esteem and feelings resulting from the publication. In some cases, notably in Reynolds itself and recently in Flood, ${ }^{63}$ the courts have emphasised the damage to the claimant's standing likely to result from the publication as a factor to be considered when striking the balance between the two rights.

Indeed, a greater focus on the likely repercussions of the allegations on the claimant's reputation is probably required by European Court jurisprudence. The Grand Chamber of the Court in Pedersen emphasised that the television documentaries alleged that the claimant, a police superintendent, had deliberately suppressed evidence - a grave accusation, not just one of general incompetence. ${ }^{64}$ Charges against the integrity of a politician may destroy his public life and should be justified by the evidence or made only on the basis of very reliable information. ${ }^{65}$ It is therefore right to take account of the seriousness of the allegations and their likely impact on the claimant when striking a fair balance between the right to respect for private life and the exercise of the right to freedom of expression.

62 See the text at n. 28 above.

63 Flood, n. 13 above, para. 75 (per Lord Neuberger MR).

64 Pedersen v Denmark (2006) 42 EHRR 24.

65 Rumyana v Bulgaria, Decision of 14 February 2008, para. 61. 


\section{(III) The APPLICATION OF REYNOLdS TO THE INTERNET}

The Reynolds defence does not apply only to the traditional mass media. That was decided by the Privy Council in Seaga $\mathrm{v}$ Harper. ${ }^{66}$ It would clearly be wrong for the press and broadcasting media to enjoy defences to defamation actions which are not shared by ordinary individuals and by the publishers, for example, of academic and scientific journals or of leaflets circulated in a local community. Indeed, for that reason, the Supreme Court of Canada concluded that the term "responsible communication" should be used, rather than "responsible journalism", because the latter suggests the defence is (largely) confined to the traditional media.

It is more difficult to decide how the requirements of the responsible journalism test should be applied to bloggers, the controllers of websites and to the senders of emails. As yet, there is little authority on the application of the test to these defendants, although in Flood the Court of Appeal upheld Tugendhat J's decision that the failure of The Times to remove the defamatory allegation from its website after the MPS inquiry had cleared the claimant was not responsible journalism: once the newspaper had become aware of the result of that investigation, it should either have removed the defamatory material or attached an appropriate qualification. ${ }^{67}$ The author of the leading book on the application of libel law to the internet has suggested that the requirements of responsible journalism should be applied to take account of the limited resources enjoyed by bloggers - compared with those of professional journalists - to check their stories and to contact potential defamation claimants. ${ }^{68}$ But any latitude would be of little comfort to the victims of defamatory attacks whose reputation may be destroyed instantaneously and globally by an email or on a website. Another point is that the public interest requirement may be difficult to apply, when the readership is international, ${ }^{69}$ though there is no obvious reason why publication on the internet should in this respect be treated differently from publication in a journal or magazine with an international circulation. ${ }^{70}$

These questions will surely have to be answered soon by the courts. The report of the Joint Committee of the House of Lords and the House of Commons examining the government's Draft Defamation Bill recommended that the "resources" of the publisher should be added to the list of factors to be considered by the courts when determining whether the defendant has acted responsibly. It would be wrong in its view to expect an individual blogger (or for that matter a local newspaper) to carry out as many prepublication checks as a national newspaper or broadcaster, in order to satisfy the requirements of responsible publication. ${ }^{71}$ On the other hand, there is no reason why the online version of a national paper should not be treated in the same way as the print version for the purposes of the test. The point is that the requirements should be applied flexibly, taking account of the defendant's practical ability to verify the truth of the allegations.

\section{Reynolds and reportage}

The courts have developed a defence of reportage, usually regarded as a variant or species of Reynolds privilege, under which the media (or other defendant) can argue that it is in the

66 [2009] AC 1.

67 See n. 13 above, paras 77-83.

68 M Collins, The Law of Defamation and the Internet 3rd edn (Oxford: OUP 2010), para. 13.43.

69 Ibid. para. 13.40-41.

70 The High Court of Australia in Dow Jones v Gutnick (2002) 210 CLR 575 rejected the argument that there should be special rules for the internet with regard to jurisdiction in libel actions.

71 See n. 36, para. 65a. 
public interest for it to report neutrally the allegations in a dispute between two (or more) parties. ${ }^{72}$ In these circumstances it is the fact that certain allegations have been made which is important, not whether they are true or false. ${ }^{73}$ There is no duty in this context for the media to check the accuracy of the allegations it is reporting, for their truth is irrelevant. But in the leading case on reportage, ${ }^{74}$ it was said that the other elements of Reynolds privilege have to be satisfied; for example, the information published must be in the public interest, while the seriousness of the allegations and whether it was urgent to report them should be considered. But they may be applied in a different way in a reportage case. In Roberts v Gable, it was unnecessary for the reporter to ask for the claimants' comments, since their side of the dispute (between leading members of the British National Party) could be inferred from the report.

There are a number of odd aspects to the development of a common law reportage defence, now incorporated in the government's Draft Defamation Bill. ${ }^{75}$ First, as has been pointed out, ${ }^{76}$ it weakens the impact of the repetition rule, under which the defendant cannot justify the republication of a defamatory allegation by showing that it has been reported accurately. The defendant must prove the truth of the allegation that has been republished. Reportage provides a qualified privilege defence in these circumstances, if the republication is in the public interest - because the general public has an interest in knowing that an allegation has been made in the course of a dispute. Logically, the availability of the qualified privilege defence can be regarded as compatible with the repetition rule, an aspect of the defence of truth, but it certainly weakens the impact of that rule.

What has less often been discussed is the impact of reportage on statutory qualified privilege. Under the Defamation Act 1996 there is qualified privilege for the fair and accurate reports of a number of proceedings, statements, notices and other matters itemised in the Schedule to the Act; in some circumstances, the privilege is subject to the condition that the defendant had published a reasonable explanation or contradiction of the publication when called on by the claimant to do this. ${ }^{77}$ What is surprising is that the courts have developed a common law qualified privilege defence for reports of defamatory allegations, at least if made in the course of a dispute, when Parliament has specifically listed a set of proceedings and other statements and notices for which a fair reporting defence can be invoked. It can surely be argued that the implication of these specific provisions is that in other circumstances fair and accurate reports are not covered by qualified privilege. Moreover, the common law reportage defence may be claimed whether or not the media has published any explanation of the report which may have been requested by the claimant.

Arguably the conservative decision of the Court of Appeal in Flood was partly influenced by its anxiety not to extend further the statutory reporting defences provided by the Defamation Act 1996. Reportage itself was not invoked; it probably could not have been, since The Times was not explicitly reporting a dispute and it did not name the source who had made the detailed allegations against DS Flood which the newspaper was

72 In Galloway v Daily Telegraph Group Ltd [2006] EMLR 11 the Court of Appeal might have been prepared to allow the reportage defence if the paper had not embellished the allegations against Galloway found in a document. That suggests the defence is not confined to the reports of disputes; also see Sedley LJ in Charman v Orion Publishing Ltd [2008] 1 All ER 750, para. 91.

73 See Latham LJ in Al-Fagib v HH Saudi Research and Marketing Ltd [2002] EMLR 13, para. 65 (CA).

74 Roberts v Gable [2008] QB 502, (CA), para. 61.

75 Cl. 2(3).

76 See I Loveland, "The ongoing evolution of Reynolds privilege in domestic libel law" (2003) 14 Entertainment Law Review 178, p. 179, and Bosland, "Republication of defamation", n. 14 above, pp. 96-7.

77 Defamation Act 1996, s. 15. 
reporting. (It is arguable that The Times was reporting, implicitly, a dispute between Flood and its source, ${ }^{78}$ but that point perhaps shows how open-ended the concept of a "dispute" is in this context.) The Court of Appeal did hold that Reynolds privilege could be invoked in principle for a report of allegations made to the police (about a police officer), in addition to the statutory privilege covering the report of the police statement that an investigation was being conducted into these allegations. ${ }^{79}$ But Lord Neuberger MR was explicitly reluctant in effect to extend the statutory privilege "by refracting [the report of the police statement] through the prism of editorial control, so that the report of the allegations which gave rise to the investigation are also privileged" at common law. ${ }^{80}$

It would be wrong to extend the reportage defence too far. If it covered, as the Court of Appeal in Galloway has suggested, the neutral reporting of defamatory allegations made outside the context of a dispute, or if it covered the reporting of any "private" dispute between celebrities, of no real public interest, it would provide the media with very generous protection from libel proceedings. In his recent article on the defence, Jason Boland is right to argue for a narrow scope for reportage, which should in his view be confined to the neutral reporting of allegations where there is a public interest in the fact that they have been made. ${ }^{81} \mathrm{I}$ am not convinced, however, that it is necessary, as he argues, to divorce reportage entirely from Reynolds, so that the factors itemised by Lord Nicholls are to be treated as irrelevant. In the first place, it is surely right to require that the allegations made in the course of the dispute raise a matter of public concern - the first threshold requirement for the Reynolds defence. ${ }^{82}$ It is difficult to see what real public interest there could be in a dispute - even one between two celebrities - unless the allegations reported as being made in the course of that dispute are of public concern. It is not easy to see what the public interest might be in the making of allegations as such, entirely divorced from their nature or subject-matter. Secondly, to take one of the Reynolds factors, the reliability of the source of the report may sometimes be important. It is not necessary, as it is in the ordinary Reynolds case, for the reporter to believe the truth of any of the allegations made in the reported dispute, but it is surely reasonable to expect the reporter to believe that the allegations were actually made in the course of the dispute and that the dispute was not wholly invented. The factors in the Reynolds check-list for responsible journalism may need to be modified for reportage, but they should not be discarded or treated as altogether irrelevant.

The larger questions are, however, these. First, should a reportage defence have been developed at all by the courts, given the provision of some fair reporting defences by the Defamation Act 1996? The statutory privilege typically covers the fair and accurate reports of a range of public meetings, fair and accurate copies of documents circulated to members of a public company, and comparable reports of decisions taken by various associations formed to promote, for example, learning, a trade or profession, sports or charitable objects. ${ }^{83}$ In contrast, the common law reportage defence provides protection for the reporting of "disputes" of an informal character, which may be conducted largely in private, but which are nevertheless of public interest. The reporting of disputes of this kind is the concern of the press and other media in the course of investigative journalism. But if that provides some argument for the development of reportage, the second question

78 I am indebted to Paul Mitchell for this point.

79 Flood, n. 13 above, paras 30-7.

80 Ibid. para. 65.

81 Bosland, "Republication of defamation", n. 14 above

82 See the text at n. 31 above.

83 Defamation Act 1996, Sch. 1. 
arises: would it not be right to treat the reportage cases simply as instances of Reynolds qualified privilege, where it would be wrong to insist on the duty to verify or check every defamatory allegation? It would be a mistake to take reportage any further, particularly as it might well encourage lazy and sloppy journalism to the cost of reputation rights. ${ }^{84}$ In this context it is interesting to note that the Joint Committee on the Draft Defamation Bill has recommended that cl. 2(3) of the Bill (the statutory version of the reportage defence) should be reformulated to make it clear that the neutral reporting of a dispute should form one of the factors in determining whether the defendant acted responsibly in publishing a defamatory allegation. Reportage as part of an accurate and impartial account of a dispute should not, as the Draft Bill provides, necessarily be treated as a responsible publication. ${ }^{85}$ In short, the reportage defence should not be divorced entirely from consideration of the other factors taken into account in determining responsible journalism.

Two conclusions can be drawn from these rather diffuse reflections on Reynolds and reportage - two new, closely related, heads of qualified privilege defence. The first is that while Reynolds privilege represents a laudable attempt to enhance freedom of expression and of the press in the context of libel actions, it hardly removes the chilling effect of libel law. Moreover, when it is successfully invoked, it leaves the claimant without any redress, even though the claimant has probably been the victim of an inaccurate defamatory allegation. This is surely very unsatisfactory. Secondly, reportage fits uneasily with both the repetition rule and with the provision of specific, but limited, defences for fair and accurate reports by the Defamation Act 1996. That does not, of course, mean that the defence is an aberration. But it shows perhaps the difficulties of judicial reform of this complex area of law, and how hard it is to strike a fair balance between freedom of expression and the right to reputation.

84 See G Busitill, "Reportage: a not entirely neutral report" (2009) Entertainment Law Review 44.

85 Joint Committee, n. 36 above, para. 66. 